\title{
Does Pregnancy-Associated Breast Cancer Imply a Worse Prognosis? A Matched Case-Case Study
}

\author{
Constantine Dimitrakakis $^{\mathrm{a}}$ Flora Zagouri $^{\mathrm{b}} \quad$ Alexandra Tsigginou $^{\mathrm{a}}$ \\ Spyros Marinopoulos ${ }^{a}$ Theodoros N. Sergentanis ${ }^{c}$ Antonis Keramopoulos ${ }^{a}$ \\ George C. Zografos ${ }^{c}$ Konstantina Ampela ${ }^{a}$ Dimosthenis Mpaltas ${ }^{a}$ \\ Christos Papadimitriou $^{b}$ Meletios-Athanassios Dimopoulos $^{b}$ Aris Antsaklis $^{a}$ \\ aDepartment of Obstetrics and Gynecology Alexandra Hospital, \\ ${ }^{b}$ Department of Clinical Therapeutics, Alexandra Hospital, \\ ${ }^{\mathrm{c}}$ 1st Propaedeutic Surgical Department, Hippocrateio Hospital, University of Athens, Greece
}

\section{Keywords}

Breast cancer · Pregnancy · Survival · Prognosis

\section{Summary}

Background: Significant controversy exists in the literature regarding the role of pregnancy in the prognosis of breast cancer. We designed a matched case-case study, matching pregnancy-associated breast cancer (PABC) cases with breast cancer cases for stage, age, and year of diagnosis. Patients and Methods: 39 consecutive cases of PABC were matched with 39 premenopausal cases of breast cancer. Univariate and multivariate survival analyses followed by adjustment for stage, grade, estrogen receptor status, and age at diagnosis, were performed. Results: Regarding overall survival (OS), univariate analysis pointed to longer OS in non-PABC cases vs. PABC cases. Accordingly, a more advanced stage predicted shorter survival. In the multivariate analysis, the independent aggravating effect mediated by pregnancy persisted. Interestingly, a post hoc nested analysis within PABC cases indicated that the 3rd trimester pointed to shorter OS. The aforementioned results on OS were also replicated during the examination of relapse-free survival. Conclusion: Implementing a matched case-case design, the present study points to pregnancy as a poor prognostic factor for breast cancer.

\author{
Schlüsselwörter \\ Mammakarzinom - Schwangerschaft - Überleben . \\ Prognose
}

\section{Zusammenfassung}

Hintergrund: Die Auswirkungen einer Schwangerschaft auf die Prognose des Mammakarzinoms werden in der Literatur kontrovers diskutiert. Wir haben eine gepaarte Fall-Fall-Studie konzipiert, in der schwangerschaftsassoziierte Mammakarzinom (SAM)-Fälle entsprechend ihres Stadiums, Alters und Jahr der Diagnosestellung mit Mammakarzinom-Patientinnen gepaart wurden. Patientinnen und Methoden: 39 aufeinanderfolgende SAMFälle wurden mit 39 prämenopausalen Fällen von Brustkrebs gepaart. Univariate und multivariate Überlebensanalysen mit Anpassung an Stadium, Grad, Östrogenrezeptorstatus und Alter zum Zeitpunkt der Diagnose wurden durchgeführt. Ergebnisse: Hinsichtlich des Gesamtüberlebens deutete die univariate Analyse auf ein längeres Gesamtüberleben für nicht-SAM-Fälle vs. SAMFälle hin. Gleichzeitig war ein fortgeschritteneres Stadium ein Prädiktor für ein kürzeres Überleben. Die multivariate Analyse bestätigte die unabhängige verschlechternde Auswirkung einer Schwangerschaft. Interessanterweise ergab eine genestete Post-hoc-Analyse der SAM-Fälle Hinweise auf ein kürzeres Gesamtüberleben für das dritte Trimester. Die oben erwähnten Ergebnisse für das Gesamtüberleben konnten desweiteren bei der Untersuchung des rezidivfreien Überlebens reproduziert werden. Schlussfolgerung: Mit ihrem gepaarten Fall-Fall-Design deutet die vorliegende Studie darauf hin, dass Schwangerschaft ein schlechter Prognosefaktor beim Mammakarzinom ist.

\section{KARGER}

Fax +497614520714

Information@Karger.com

www.karger.com (c) 2013 S. Karger GmbH, Freiburg

1661-3791/13/0083-0203\$38.00/0

Accessible online at:

www.karger.com/brc 


\section{Introduction}

Pregnancy-associated breast cancer (PABC) is defined as breast cancer occurring anytime during gestation, lactation, or within 1 year after delivery $[1,2]$. The incidence of PABC varies between 1:3,000-10,000 per number of gestations; as a result, it is the 4th most frequent malignancy emerging during pregnancy after malignant melanoma, cervical cancer, and lymphoma [3]. The incidence of PABC may well be rising, as women are now more inclined to delay childbearing [3-6]. The role of pregnancy in the prognosis of breast cancer remains controversial. Many studies did not suggest any significant associations [7-13], whereas others attributed any detrimental effects solely on the delayed diagnosis of tumors in pregnancy [14-18]. On the contrary, some studies pointed to the opposite direction, indicating an independent poor prognostic role of pregnancy [19-21]. From a methodological point of view, the aforementioned may imply that the elucidation of the effects mediated by pregnancy may to a certain extent be challenging, as the advanced stage of tumors diagnosed during pregnancy seems to represent a confounding factor. In an attempt to circumvent this issue, we designed a matched case-case study, matching PABC cases with breast cancer cases for stage (as well as age and year of diagnosis, secondarily) to obtain a clearer picture of the underlying phenomena. Of note, despite the crucial role mediated by stage, the majority of published studies have not performed matching by stage $[8,14,15,17,20]$.

\section{Patients and Methods}

Patients were recruited during a nearly 30-year period (1979-2010) in 2 tertiary reference centers (Department of Obstetrics and Gynecology, Alexandra General Hospital; First Department of Propaedeutic Surgery, Hippokrateion General Hospital, Athens, Greece). 39 consecutive cases of $\mathrm{PABC}$ were identified through a detailed database; 39 premenopausal cases of breast cancer matched for stage, age ( \pm 3 years) and year of diagnosis ( \pm 3 years) were accordingly recruited. Data regarding chemotherapy regimens (anthracycline-based chemotherapy or anthracycline plus taxane chemotherapy) and radiotherapy (yes vs. no) were available after 1997, therefore cases diagnosed after 1997 were additionally matched for chemotherapy and radiotherapy. A centralized histological review of all cases and controls has been performed. The histological type, grade, estrogen receptor (ER), progesterone receptor (PgR), and c-erbB-2 status were recorded for all cases.

For immunohistochemistry (IHC), the following antibodies were used: PgR (PgR 636, Dako, Glostrup, Denmark), ER (ID5, Dako), and c-erbB-2 (CB11, Novocastra, Newcastle-upon-Tyne, UK). Sections (4 $\mu \mathrm{m}$ thick) cut from formalin-fixed paraffin-embedded tissue were used. After deparaffinization in xylene and hydration in graded ethanol solutions, the sections of breast carcinoma tissue were subjected to pretreatment in order to enhance antigen retrieval. The EnVision ${ }^{\circledR}+$ System HRP (DAB) (DakoCytomation, Glostrup, Denmark) was used with primary antibodies against the following antigens: PgR, ER, and c-erbB-2. IHC was performed according to the protocols provided by the manufacturer. Concerning the immunohistochemical expression of ER and PR, both the intensity (negative, $1+$ to $3+$ ) and the percentage of immunopositive
Table 1. Descriptive statistics of the study sample

\begin{tabular}{|c|c|c|c|}
\hline Categorical variables & $\begin{array}{l}\text { PABC } \\
\text { cases }\end{array}$ & $\begin{array}{l}\text { Non-PABC } \\
\text { cases }\end{array}$ & $\mathrm{p}$ \\
\hline $\begin{array}{l}\text { Mean age at diagnosis } \pm \text { SD, } \\
\text { years }\end{array}$ & $34.3 \pm 5.0$ & $33.9 \pm 4.5$ & $0.678^{\mathrm{a}}$ \\
\hline Stage, n (\%) & & & matched \\
\hline I & $1(2.5)$ & $1(2.5)$ & \\
\hline II & $20(51.3$ & $20(51.3)$ & \\
\hline III & $15(38.5)$ & $15(38.5)$ & \\
\hline IV & $3(7.7)$ & $3(7.7)$ & \\
\hline Grade, n (\%) & & & $0.113^{\mathrm{b}}$ \\
\hline 1 & $1(2.6)$ & $0(0.0)$ & \\
\hline 2 & $3(7.9)$ & $9(23.7)$ & \\
\hline 3 & $34(89.5)$ & $29(76.3)$ & \\
\hline \multicolumn{4}{|l|}{$\begin{array}{l}\text { Time at diagnosis regarding } \\
\text { pregnancy, } \mathrm{n}(\%)\end{array}$} \\
\hline 1st trimester & $3(7.7)$ & NA & \\
\hline 2nd trimester & $6(15.4)$ & NA & \\
\hline 3rd trimester & $17(43.6)$ & NA & \\
\hline $\begin{array}{l}\text { Puerperium to } 1 \text { year after } \\
\text { pregnancy }\end{array}$ & $13(33.3)$ & NA & \\
\hline Histological type, n (\%) & & & $0.761^{\mathrm{c}}$ \\
\hline Ductal & $32(82.1)$ & $33(84.6)$ & \\
\hline Lobular & $7(17.9)$ & $6(15.4)$ & \\
\hline $\begin{array}{l}\text { Estrogen receptor status, } \\
\mathrm{n}(\%)\end{array}$ & & & $0.602^{b}$ \\
\hline Negative & $22(56.4)$ & $16(41.0)$ & \\
\hline $1+$ & $8(20.5)$ & $9(23.1)$ & \\
\hline $2+$ & $3(7.7)$ & $5(12.8)$ & \\
\hline $3+$ & $6(15.4)$ & $9(23.1)$ & \\
\hline $\begin{array}{l}\text { Progesterone receptor status, } \mathrm{n} \\
(\%)\end{array}$ & & & $0.455^{\mathrm{b}}$ \\
\hline Negative & $23(59.0)$ & $17(43.6)$ & \\
\hline $1+$ & $9(23.1)$ & $11(28.2)$ & \\
\hline $2+$ & $4(10.2)$ & $4(10.2)$ & \\
\hline $3+$ & $3(7.7)$ & $7(18.0)$ & \\
\hline c-erbB-2 status, n (\%) & & & $0.894^{\mathrm{b}}$ \\
\hline Negative & $32(82.0)$ & $33(84.6)$ & \\
\hline $1+$ & $2(5.1)$ & $3(7.7)$ & \\
\hline $2+$ & $1(2.6)$ & $1(2.6)$ & \\
\hline $3+$ & $4(10.3)$ & $2(5.1)$ & \\
\hline Chemotherapy, n (\%) & & & matched \\
\hline Anthracycline-based & $8(20.5)$ & $8(20.5)$ & \\
\hline Taxane-based & $1(2.6)$ & $1(2.6)$ & \\
\hline Anthracycline plus taxane & $12(30.8)$ & $12(30.8)$ & \\
\hline Other & $1(2.6)$ & $1(2.6)$ & \\
\hline Missing & $17(43.6)$ & $17(43.6)$ & \\
\hline Radiotherapy, n (\%) & & & matched \\
\hline Yes & $15(38.5)$ & $15(38.5)$ & \\
\hline No & $7(17.9)$ & 7 (17.9) & \\
\hline Missing & $17(43.6)$ & $17(43.6)$ & \\
\hline Hormone therapy, n (\%) & & & $0.365^{\mathrm{c}}$ \\
\hline Yes & $10(25.6)$ & $13(33.3)$ & \\
\hline No & $12(30.8)$ & $9(23.1)$ & \\
\hline Missing & $17(43.6)$ & $17(43.6)$ & \\
\hline $\begin{array}{l}\text { Trastuzumab administration, } \mathrm{n} \\
(\%)\end{array}$ & & & $>0.999^{\mathrm{b}}$ \\
\hline Yes & $2(5.1)$ & $2(5.1)$ & \\
\hline No & $20(51.3)$ & $20(51.3)$ & \\
\hline Missing & $17(43.6)$ & $17(43.6)$ & \\
\hline Site of relapse, n (\%) & & & $<0.001^{\mathrm{b}}$ \\
\hline None & $12(30.7)$ & $29(74.4)$ & \\
\hline Bones & $3(7.7)$ & $3(7.7)$ & \\
\hline Visceral & $21(53.9)$ & $5(12.8)$ & \\
\hline Locoregional & $3(7.7)$ & $2(5.1)$ & \\
\hline
\end{tabular}

${ }^{\text {b} F i s h e r ' s ~ e x a c t ~ t e s t . ~}$

${ }^{a}$ Mann-Whitney-Wilcoxon test for independent samples.

'Pearson's chi square test.

$\mathrm{SD}=$ Standard deviation $; \mathrm{PABC}=$ pregnancy-associated breast cancer; $\mathrm{NA}=$ not applicable. 
Table 2. Results of multivariate Cox regression analysis for overall survival

\begin{tabular}{lllr}
\hline Variables & Category or increment & HR $(95 \% \mathrm{CI})$ & $\mathrm{p}$ \\
\hline Pregnancy & yes vs. no & $9.28(2.94-29.27)$ & $<0.001$ \\
Stage & 1 level increase & $5.32(2.50-11.29)$ & $<0.001$ \\
Estrogen receptor status & positive vs. negative & $1.25(0.51-3.06)$ & 0.623 \\
Grade & 1 level increase & $2.61(0.82-8.29)$ & 0.103 \\
Age at diagnosis & 1 year increase & $0.96(0.86-1.07)$ & 0.456 \\
\hline
\end{tabular}

HR = Hazard ratio; 95\% CI = 95\% confidence interval. cells were evaluated. Tumors with any detectable ( $\geq 1 \%)$ expression of ER and/or PgR by IHC were considered hormone receptor-positive [22].

The expression of c-erbB-2 was assessed as follows: i) negative, when no staining was documented or when membrane staining was present in less than $10 \%$ of tumor cells, ii) weak staining $(+)$, when partial membrane staining was documented in more than $10 \%$ of tumor cells, iii) moderate staining $(++)$ when weak/moderate complete membrane staining was present in more than $10 \%$ of tumor cells, and iv) strong staining, when strong complete membrane staining was observed in more than $10 \%$ of tumor cells. Cases with negative and weak c-erbB-2 staining were considered as negative, whereas cases with strong c-erbB-2 staining were considered as positive. In cases with moderate staining, chromogenic in situ hybridization (CISH) was performed; subsequently these cases were considered as negative or positive. In all cases, 10 fields $(\times 40$ magnification) were assessed, and a minimum of 100 cells were evaluated in the designated areas, to appraise the lesion as a whole. IHC evaluation was performed independently by 2 consultant histopathologists.

For the evaluation of the factors possibly associated with overall survival and relapse-free survival (RFS), a standard 2-step approach was followed: univariate and multivariate survival analysis. At the univariate analysis, log-rank tests were appropriately performed for binary variables, while univariate Cox regression models were implemented for ordinal (stage, grade) or continuous (age) variables. At the multivariate analysis, multivariate Cox regression was performed. Statistical analysis was performed using STATA 11.1 statistical software (Stata Corporation, College Station, TX, USA).

This study was approved by the local Institutional Review Board.

\section{Results}

A description of the study sample is presented in table 1 . Regarding especially the PABC group, pregnancy was terminated in $3(7.7 \%)$ patients. Of the remaining patients, 12/36 $(33.3 \%)$ gave birth via vaginal delivery, and caesarean section was performed in $24 / 36(66.7 \%)$ cases. In 1 caesarean section case, a twin pregnancy had occurred; as a result, 37 neonates were born. The mean gestational age at delivery was 37.4 weeks (standard deviation (SD) 1.8 weeks; median 37 weeks; range 34-40 weeks). The mean birth weight was $2,870 \mathrm{~g}$ (SD $390 \mathrm{~g}$; median 2,820 g; range 2,210-3,800 g). No malformations were present at birth; all neonates were completely healthy at 18 months.

Regarding overall survival, univariate analysis pointed to longer survival in non-PABC cases vs. PABC cases (5-year survival rate 48.7 and $30.7 \%$, respectively; $\mathrm{p}<0.0001$ log-rank test) (fig. 1). Accordingly, a more advanced stage predicted shorter survival (hazard ratio $(\mathrm{HR})=5.64,95 \%$ confidence interval (CI) 2.73-11.66, increment: advancement by 1 level;

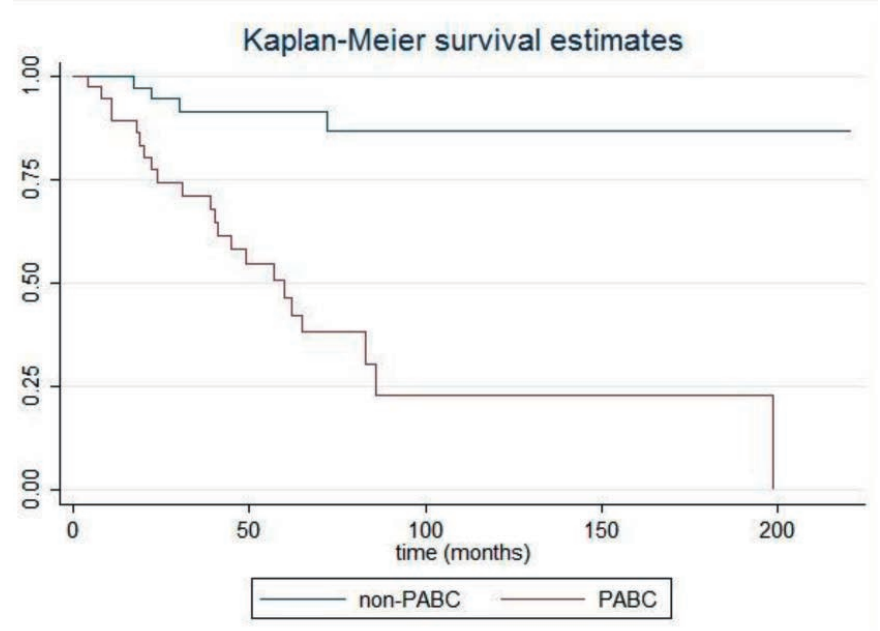

Fig. 1. Kaplan-Meier overall survival curves for pregnancy-associated breast cancer (PABC) and non-PABC cases.

$\mathrm{p}<0.001)$, whereas age at diagnosis $(\mathrm{HR}=0.95,95 \% \mathrm{CI} 0.87-$ 1.03, increment: advancement by 1 year; $\mathrm{p}=0.208)$, grade $(\mathrm{HR}=1.39,95 \%$ CI 0.54-3.54, increment: advancement by 1 level; $\mathrm{p}=0.492$ ), or ER positivity (positive vs. negative, $\mathrm{p}=0.768$ log-rank test) were not associated with overall survival. In multivariate analysis (table 2), the independent aggravating effect mediated by pregnancy persisted (HR = 9.28, 95\% CI 2.94-29.27; p < 0.001, adjusted for stage, ER status, grade, and age at diagnosis).

Interestingly, a post hoc nested analysis (adjusted for stage, grade, ER status, and age at diagnosis, as above) among the $\mathrm{PABC}$ cases indicated substantial heterogeneity regarding overall survival (fig. 2). Specifically, the median survival was 83 months for cases diagnosed in the $1 \mathrm{st} / 2$ nd trimester, 39 months for cases diagnosed in the 3rd trimester, and 62 months for cases diagnosed postpartum; with the postpartum period set as reference category, 1st/2nd trimesters did not exhibit any significant difference $(\mathrm{HR}=0.40,95 \%$ CI 0.08 1.93; $\mathrm{p}=0.251$ ), but the 3rd trimester pointed to shorter overall survival $(\mathrm{HR}=4.47,95 \%$ CI 1.55-12.87; $\mathrm{p}=0.006)$. With respect to RFS, once again PABC cases exhibited shorter RFS ( $p<0.0001, \log$-rank test). Similar to the aforementioned results for overall survival, this effect persisted in multivariate analysis, adjusted for stage, ER status, grade, and age at diagnosis. 


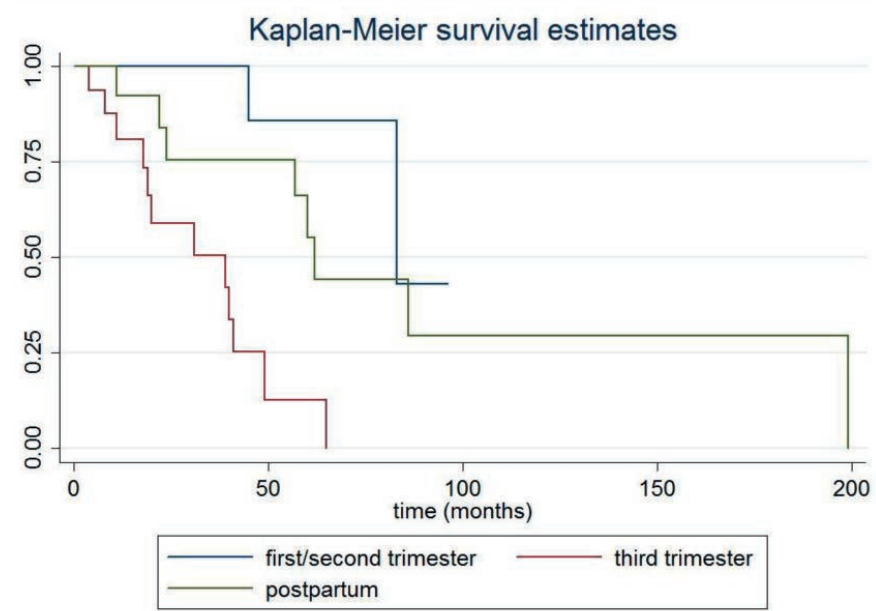

Fig. 2. Kaplan-Meier overall survival curves within pregnancy-associated breast cancer $(\mathrm{PABC})$ cases.

\section{Discussion}

Implementing a matched case-case design, the present study points to pregnancy as a poor prognostic factor for breast cancer. This effect seems to be fairly distinct to the already postulated delay in diagnosis associated with pregnancy [1417], as the matched design precluded any marked inequalities in terms of frequency distributions implicating stage. The underlying exact mechanisms remain elusive for the time being but may well be associated with the hormonal environment characterizing pregnancy. In accordance with the role of the hormonal milieu, the post hoc nested analysis among PABC cases pointed to a worse prognosis in the $3 \mathrm{rd}$ trimester where placental hormones seem fairly abundant.

Focusing on matched case-case studies, it is worth mentioning that our study is not in accordance with the study by Ibrahim et al. [23] who pointed to a lack of survival difference between patients with PABC and their matched controls. Moreover, the majority of the large population-based studies have not found inferior survival for patients with PABC [1013]. Our results seem closer to the findings of another matched study [4] which pointed to a worse prognosis, confined though exclusively to certain subgroups, i.e. postpartum.
Moreover, our results are in accordance with those recently published by Azim et al. [18]; in this well designed case-control study, PABC patients exhibited a poorer prognosis compared to age- and stage-matched controls, whilst there was no difference in tumor features between the 2 groups. In addition, our study seems in accordance with numerous unmatched studies which pointed through multivariate adjustment to an independent role of pregnancy, controlling for stage [19-21]. On the other hand, apart from smaller studies, the present report is in line with a recent population-based cohort study by Johansson et al. including 15,721 women, which essentially confirmed the findings regarding pregnancy in a large population sample [24]; however, it should be stressed that the authors did not provide any data regarding prognostic parameters of the breast cancers.

Regarding the limitations of this report, it should be declared that the chemotherapy regimen and radiotherapy data were not available for a subset of cases, i.e. those diagnosed before 1997. As a result, any modifying effects of chemotherapy and/or radiotherapy could not be reliably assessed. Moreover, another limitation of this well designed case-case study is the large timeframe of recruitment and changes in standards of care over that time. Furthermore, in our study, most patients belonged to the group with breast cancer in the 3rd trimester of pregnancy. These patients may have received treatment of lower intensity or none at all due to conflicting interests between cancer treatment and maintaining pregnancy; this may represent an explanation for the unfavorable prognosis of that group. Additionally, one cannot ignore the relative small sample size of this case-case study. It is obvious that register-based studies are more precise and are more than warranted.

In conclusion, this study portrays pregnancy as a poor prognostic factor, possibly acting through multiple pathways which may surpass the existing knowledge having implicated diagnostic delays. Further studies are warranted to shed more light on this matter.

\section{Disclosure Statement}

The authors have declared no conflicts of interest.

\section{References}

1 Viswanathan S, Ramaswamy B: Pregnancy-associated breast cancer. Clin Obstet Gynecol 2011; 54:546-555.

2 Asgeirsson KS: Pregnancy-associated breast cancer. Acta Obstet Gynecol Scand 2011;90:158-166.

3 Pentheroudakis G, Orecchia R, Hoekstra HJ, Pavlidis N; ESMO Guidelines Working Group: cancer, fertility and pregnancy: ESMO Clinical Practice Guidelines for diagnosis, treatment and follow-up. Ann Oncol 2010;21(suppl 5):v266-273.
4 Halaska MJ, Pentheroudakis G, Strnad P, Stankusova H, Chod J, Robova H, Petruzelka L, Rob L, Pavlidis N: Presentation, management and outcome of 32 patients with pregnancy-associated breast cancer: a matched controlled study. Breast J 2009;15:461-467.

5 Heck KE, Schoendorf KC, Ventura SJ, Kiely JL: Delayed childbearing by education level in the United States, 1969-1994. Matern Child Health J 1997;1:81-88.
6 Litton JK, Theriault RL: Breast cancer and pregnancy: current concepts in diagnosis and treatment. Oncologist 2010;15:1238-1247.

7 Ezzat A, Raja MA, Berry J, Zwaan FE, Jamshed A, Rhydderch D, Rostom A, Bazarbashi $\mathrm{S}$ : Impact of pregnancy on non-metastatic breast cancer: a case control study. Clin Oncol (R Coll Radiol) 1999;8:367-370. 
8 Beadle BM, Woodward WA, Middleton LP, Tereffe W, Strom EA, Litton JK, Meric-Bernstam F, Theriault RL, Buchholz TA, Perkins GH: The impact of pregnancy on breast cancer outcomes in women $<$ or $=35$ years. Cancer 2009;115:11741184.

-9 Zemlickis D, Lishner M, Degendorfer P, Panzarella T, Burke B, Sutcliffe SB, Koren G: Maternal and fetal outcome after breast cancer in pregnancy. Am J Obstet Gynecol 1992;166:781-787.

10 Mueller BA, Simon MS, Deapen D, Kamineni A, Malone KE, Daling JR: Childbearing and survival after breast carcinoma in young women. Cancer 2003;98:1131-1140.

11 Ives A, Saunders C, Bulsara M, Semmens J: Pregnancy after breast cancer: population based study. BMJ 2007;334:194.

12 Kroman N, Jensen MB, Wohlfahrt J, Ejlertsen B Danish Breast Cancer Cooperative Group: Pregnancy after treatment of breast cancer - a population-based study on behalf of Danish Breast Cancer Cooperative Group. Acta Oncol 2008;47:545549.

13 De Bree E, Makrigiannakis A, Askoxylakis J, Melissas J, Tsiftsis DD: Pregnancy after breast cancer. A comprehensive review. J Surg Oncol 2010; 101:534-542.
14 Ishida T, Yokoe T, Kasumi F, Sakamoto G, Makita M, Tominaga T, Simozuma K, Enomoto K, Fujiwara K, Nanasawa T, et al.: Clinicopathologic characteristics and prognosis of breast cancer patients associated with pregnancy and lactation: analysis of case-control study in Japan. Jpn J Cancer Res 1992;83:1143-1149.

15 Zhang J, Liu G, Wu J, Lu JS, Shen KW, Han QX, Shen ZZ, Shao ZM: Pregnancy-associated breast cancer: a case control and long-term follow-up study in China. J Exp Clin Cancer Res 2003;22:2327.

16 Murphy C, Mallam D, Stein S, Patil S, Howard J, Sklarin NT, Gemignani M, Hudis C, Seidman AD: Pathologic features and outcomes of pregnancyassociated breast cancer (PABC): a case control study. J Clin Oncol 2010;28:1589.

17 Lethaby AE, O’Neill MA, Mason BH, Holdaway IM, Harvey VJ: Overall survival from breast cancer in women pregnant or lactating at or after diagnosis. Auckland Breast Cancer Study Group. Int J Cancer 1996;67:751-755.

18 Azim HA Jr, Botteri E, Renne G, Dell'orto P, Rotmensz N, Gentilini O, Sangalli C, Pruneri G, Di Nubila B, Locatelli M, Sotiriou C, Piccart M, Goldhirsch A, Viale G, Peccatori FA: The biological features and prognosis of breast cancer diagnosed during pregnancy: a case-control study. Acta Oncol 2012;51:653-661.
9 Rodriguez AO, Chew H, Cress R, Xing G, McElvy S, Danielsen B, Smith: Evidence of poorer survival in pregnancy-associated breast cancer. Obstet Gynecol 2008;112:71-78.

20 Bonnier P, Romain S, Dilhuydy JM, Bonichon F, Julien JP, Charpin C, Lejeune C, Martin PM, Piana $\mathrm{L}$ : Influence of pregnancy on the outcome of breast cancer: a case-control study. Societe Francaise de Senologie et de Pathologie Mammaire Study Group. Int J Cancer 1997;72:720-727.

21 Moreira WB, Brandão EC, Soares AN, Lucena $\mathrm{CE}$, Antunes CM: Prognosis for patients diagnosed with pregnancy-associated breast cancer: a paired case-control study. Sao Paulo Med J 2010;128:119_ 124.

22 Aebi S, Davidson T, Gruber G, Cardoso F; ESMO Guidelines Working Group: Primary breast cancer: ESMO Clinical Practice Guidelines for diagnosis, treatment and follow-up. Ann Oncol 2011;22:vi1224.

23 Ibrahim EM, Ezzat AA, Baloush A, Hussain ZH, Mohammed GH: Pregnancy-associated breast cancer: a case-control study in a young population with a high-fertility rate. Med Oncol 2000;17:293-300.

24 Johansson AL, Andersson TM, Hsieh CC, Cnattingius S, Lambe M: Increased mortality in women with breast cancer detected during pregnancy and different periods postpartum. Cancer Epidemiol Biomarkers Prev 2011;20:1865-1872. 